\title{
Sistem Pakar Penanganan Kasus Sengketa Tanah Menggunakan Metode Backward Chaining
}

\author{
Sapri 1), Khairil ${ }^{2)}$ \\ 1), 2) Universitas Dehasen Bengkulu, Jalan Meranti Raya No. 32 Sawah Lebar Bengkulu, 073622027 \\ e-mail: sapri@unived.ac.id
}

\begin{abstract}
Abstrak
Sengketa tanah adalah merupakan konflik antara dua pihak atau lebih yang mempunyai kepentingan berbeda terhadap satu atau beberapa obyek hak atas tanah yang dapat mengakibatkan akibat hukum bagi keduanya. Permasalahan untuk menjelaskan peraturan pemerintah maupun perundang-undangan berkaitan dengan kasus sengketa tanah dengan cara sederhana yaitu, dijelaskan aturan yang sesuai dengan permasalahan yang terjadi. Hal ini menyulitkan seorang pengacara yang harus menangani klien yang banyak dan kasus yang berbeda. Tujuan penelitian ini membuat Sistem Pakar Penanganan Kasus Sengketa Tanah menggunakan metode backward chaining. Penelitian dilakukan menganalisa kebutuhan yang ada, mengumpulkan data, merancang, mengimplementasikan hasil rancangan kedalam aplikasi yang digunakan, setelah itu akan dilakukan pengujian dan pemeliharaan sistem. Hasil penelitian menunjukkan bahwa dengan adanya sistem pakar ini, memberikan manfaat yang sangat berarti bagi klien yaitu memudahkan klien untuk melakukan konsultasi mengenai penanganan kasus sengketa tanah yang dihadapi.
\end{abstract}

Kata kunci: Sengketa, Sistem Pakar, Backward Chaining

\begin{abstract}
Land dispute is a conflict between two or more parties that have different interests in one or several objects of land rights that can result in legal consequences for both. Problems to explain government regulations and legislation relating to land dispute cases in a simple way that is, explained the rules that correspond to the problems that occur. This makes it difficult for a lawyer to deal with many clients and different cases. The purpose of this study is to design the Expert System for Handling Land Dispute Cases using the Backward Chaining Method. The study was conducted to analyze the existing needs, collect data, design, implement the results of the design into the application that is used, after that will be tested and maintained the system. The results of the study show that the existence of this expert system, it provides very meaningful benefits for the client, namely facilitating the client to carry out consultations regarding the handling of land dispute cases.
\end{abstract}

Keywords: Dispute, Expert System, Backward Chaining

Diterima Desember 2019

Disetujui Desember 2019

2019 Sapri, Khairil

Dipublikasi Desember 2019

Under the license CC BY-SA 4.0

\section{Pendahuluan}

Dengan berkembangnya teknologi informasi yang pesat, aplikasi memberikan peranan terhadap perkembangan teknologi. Aplikasi dapat menyelesaikan permasalahan yang diperlukan oleh siapapun yang membutuhkan. Semua yang terkait dengan kebutuhan suatu organisasi dapat di selesaikan dengan penerapan aplikasi. Sehingga dengan implementaskan aplikasi dengan teknologi akan memudahkan dalam hal pengumpulan data, pengiriman, penyimpanan dan pengolahan informasi. 
Penelitian menggunakan metode backward chaining sudah sering dilakukan, inferensi backward chaining merupakan strategi pencarian yang arahnya kebalikan dari runut mundur (Forward Chaining). Proses pencarian dimulai dari tujuan, yaitu kesimpulan yang menjadi solusi permasalahan yang dihadapi. Mesin inferensi mencari kaidah-kaidah dalam basis pengetahuan yang kesimpulannya merupakan solusi yang ingin dicapai, kemudian dari kaidah-kaidah yang di peroleh, masing-masing kesimpulan di runut balik jalur yang mengarah pada kesimpulan tersebut. (Herliana dkk, 2018).

Berdasarkan Hasil observasi pada salah satu kantor Advokat yang bergerak pada jasa konsultan hukum. Untuk menjelaskan peraturan pemerintah maupun perundang-undangan berkaitan dengan kasus sengketa tanah masih terlihat dengan cara sederhana yaitu, dijelaskan dengan aturan yang sesuai dengan permasalahan yang terjadi. Hal ini membutuhkan waktu seorang pengacara yang harus menangani banyaknya klien yang ditangani dengan kasus yang berbeda.

Persoalan ini yang membuat pemikiran untuk membantu dalam memudahkan biro jasa konsultan hukum untuk menerima konsultasi hukum. Untuk membantu konsultan hukum tersebut diperlukan aplikasi sistem pakar dalam penanganan kasus sengketa tanah agar menjadi lebih efisien dan efektif. Aplikasi ini juga memberikan manfaat bagi seorang pengacara dalam melayani masyarakat dalam berkonsultasi tentang kasus sangketa tanah, karena cukup dibantu oleh admin untuk menjalankan aplikasi sistem pakar.

Menurut Arhami dan Muhamad (dalam Mulyani dkk, 2015) Suatu sistem pakar adalah suatu sistem komputer yang menyamai (emulates ) kemampuan pengambilan keputusan dari seorang pakar. Basis pengetahuan yang diperoleh, diambil dari pengalaman seorang pakar maupun teori-teori yang ada pada bidang yang spesifik saja, oleh karena itu sistem pakar memiliki keterbatasan.

Dibangunnya sistem pakar penanganan kasus sengketa tanah yang terintegrasi dengan komputer, tentunya dapat mewakili seorang ahli dalam menangani kasus tersebut. Hal ini yang akan membantu lawyer menangani klien memecahkan masalah sengketa tanah yang jumlahnya banyak dengan kasus berbeda. Terbangunnya sistem pakar ini awal langkah meningkatkan profesionalisme kerja seorang lawyer dalam hal pekerjaan, di mana klien yang banyak mengalami kasus yang berbeda dapat diselesaikan dalam waktu yang singkat, tepat dan memiliki informasi yang akurat.

Menurut (Suryadi, 2005) sistem pakar atau expert sistem adalah sebuah perangkat lunak komputer yang memiliki basis pengetahuan untuk domain tertentu dan 
menggunakan penalaran inferensi menyerupai seorang pakar dalam memecahkan masalah. sistem dapat disebut sistem pakar jika memiliki ciri tertentu. Hal ini juga harus didukung oleh komponen sistem pakar yang mampu menggambarkan tentang ciri dan karakteristik.

Dari pendapat ahli di atas sistem pakar dapat didefinisikan program komputer yang bertindak sebagai konsultan. Dengan adanya sistem pakar, seseorang pemakai dapat berkonsultasi dalam memecahkan masalah layaknya berkonsultasi langsung dengan seorang pakar sesuai dengan domain masalah tertentu yang diinput ke dalam sistem pakar tersebut. Pengetahuan yang digunakan dalam sistem pakar khusus untuk satu problem domain sebagai kebalikan dari pengetahuan tentang teknik pemecahan masalah pada umumnya.

Tujuan penelitian ini adalah membuat Sistem pakar untuk penanganan kasus sengketa tanah pada Kantor Advokat menggunakan metode Backward Chaining. Penerapan teknologi artificial inteligent di bidang hukum dengan mebuat aplikasi sistem pakar untuk efisiensi konsultasi hukum penanganan kasus sangketa tanah.

\section{Metode}

Metode penelitian yang digunakan dalam merancang sistem pakar penanganan kasus sengketa tanah adalah metode pengembangan sistem dimulai dengan menganalisa kebutuhan yang ada, mengumpulkan data, merancang, mengimplementasikan hasil rancangan kedalam aplikasi yang digunakan, setelah itu akan dilakukan pengujian dan pemeliharaan sistem.

Metode pengumpulan data yang digunakan didapatkan dari berbagai sumber diantaranya buku, internet dan sumber-sumber lainnya. Dalam melakukan penelitian menggunakan beberapa cara metode pengumpulan data yaitu :

a. Observasi

Pada penelitian ini dilakukan pengumpulan data dengan cara melakukan pengamatan secara langsung pada objek yang diteliti yaitu mengenai kasus sengketa tanah pada kantor Advokad Eka Septo S.H dan Rekan.

b. Wawancara

Suatu teknik pengumpulan data dengan cara dialog (tanya jawab) secara langsung dengan Advokad dan Rekan.

c. Studi Pustaka

Pada penelitian ini dilakukan pengumpulan data dengan cara pengumpulan data dengan mengambil dari sumber buku, jurnal, dan lain-lain yang berhubungan dengan Sengketa Tanah. 
Metode Backward Chaining (Suryadi, 2005) merupakan strategi pencarian yang arahnya kebalikan dari runut maju (forward chaning). Proses pencarian dimulai dari tujuan, yaitu kesimpulan yang menjadi solusi permasalahan yang dihadapi. Mesin inferensi mencari kaidah-kaidah dalam basis pengetahuan yang kesimpulannya merupakan solusi yang ingin dicapai, kemudian dari kaidah-kaidah yang diperoleh, masing-masing kesimpulan dirunut balik jalur yang mengarah ke kesimpulan tersebut. Jika informasi-informasi atau nilai dari atribut-atribut yang mengarah ke kesimpulan tersebut sesuai dengan data yang diberikan maka kesimpulan tersebut merupakan solusi.

Pelacakan ke belakang ( backward chaining) yang memulai penalaran dari kesimpulan hipotesa menuju fakta yang mengandung hipotesa tersebut. Dan yang kedua yakni pelacakan ke depan ( forward chaining) yang merupakan kebalikan dari pelacakan kebelakang yaitu memulai dari sekumpulan data menuju kesimpulan (Desiani dan Arhami, 2006). Bebeda dengan pandangan (Kusrini, 2006) Backward chaining atau runut balik merupakan metode penalaran kebalikan dari runut maju. Dalam runut balik, penalaran dimulai dengan tujuan merunut balik ke jalur yang akan mengarahkan ke tujuan metode tersebut.

Menurut Bill Brandon, dalam (Dahria, 2012) Backward chaining memulai proses pencarian dengan suatu tujuan sehingga strategi ini disebut juga goal-driven (Pelaksanaan kebelakang). Proses pencarian dengan metode Backward chaining tersebut dapat dilihat pada gambar 1.

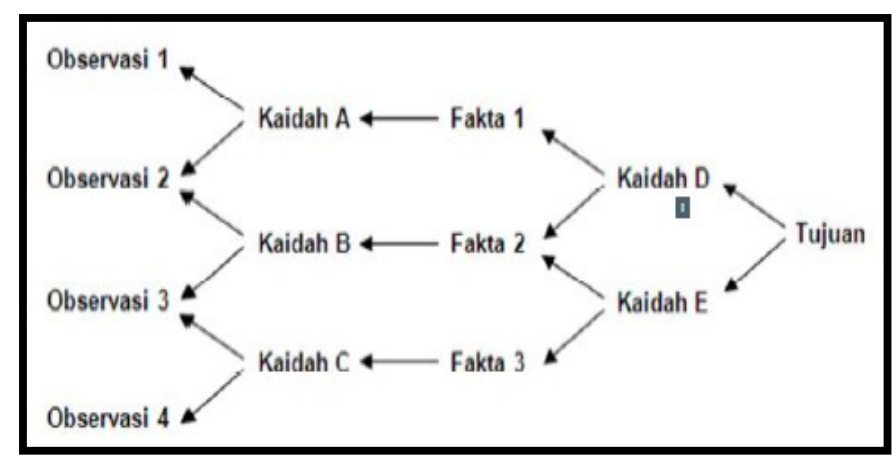

Gambar 1. Diagram Pelacakan Kebelakang 
Berikut ini diuraikan langkah-langkah untuk mengimplentasikan Backward chaining menurut Bill Brandon, (2003) dalam Dahria (2012:43)

1. Identifikasi konklusi sebagai goal utama.

2. Cari konklusi list untuk pengisian pertama sekali dari nama konklusi. Jika ketemu, tempatkan rule pada conclusionstack berdasarkan nomor rule dan satu yang mempresentasikan nomor klausa

3. Jika tujuan utama tidak ditemukan, maka inference engine akan mencari sebuah tujuan baru yang dijadikan sub goal untuk menemukan IF_part dari sebuah rule.

4. Kemudian knowledge base akan mencocokkan lagi aturan-aturan sehingga menemukan sub goal.

5. Selanjutnya inference engine akan mengulang kembali proses pencarian rule hingga tidak menemukan rule di dalam knowledge base.

Dengan demikian Backward chaining adalah penalaran dari kesimpulan sementara menuju kebenaran yang sebenarnya sesuai dengan fakta itu sendiri.

\section{Hasil dan Pembahasan}

Setelah dilakukan penelitian dengan tahapan-tahapan seperti; uji kelayakan topik penelitian, pengumpulan data, analisa sistem aktual, dan perancangan sistem baru, maka dibangun perangkat lunak sebagai sistem pakar yang menggunakan metode Backward Chaining dalam melakukan penanganan kasus sengketa tanah.

Perangkat lunak yang dikembangkan adalah aplikasi berbasis desktop yang terintegrasi ke database MySQL. Aplikasi yang dibangun dapat menampung inputan, memproses data dan melakukan penghitungan dengan menggunakan metode Backward Chaining, serta menghasilkan output berupa laporan hasil konsultasi.

\section{Hasil}

Pengujian dalam pengembangan aplikasi sistem pakar ini sangat penting bertujuan untuk menemukan kesalahan-kesalahan pada sistem yang telah dibuat sesuai dengan yang direncanakan. Pengujian ini berfokus pada fungsi dari sistem pakar untuk mengetahui apakah aplikasi ini berfungsi dengan benar. Tabel 1 adalah hasil pengujian sistem pakar menggunakan metode black box testing

Tabel 1. Hasil Pengujian Sistem

\begin{tabular}{|c|c|c|c|c|c|}
\hline \multirow[t]{2}{*}{ No } & \multirow[t]{2}{*}{ Modul } & \multirow[t]{2}{*}{ Data Masuk } & \multirow[t]{2}{*}{ Hasil Yang Diharapkan } & \multicolumn{2}{|c|}{$\begin{array}{c}\text { Hasil } \\
\text { Pengujian } \\
\end{array}$} \\
\hline & & & & Sesuai & Tidak \\
\hline 1. & $\begin{array}{l}\text { Menu Jenis } \\
\text { Kasus }\end{array}$ & $\begin{array}{l}\text { KlikTombol } \\
\text { Tambah }\end{array}$ & $\begin{array}{l}\text { Form akan kosong dan aktif siap } \\
\text { untuk entri data }\end{array}$ & $\sqrt{ }$ & \\
\hline & & $\begin{array}{l}\text { Klik Tombol } \\
\text { simpan }\end{array}$ & $\begin{array}{l}\text { Data jenis kasus akan } \\
\text { bertambah dan akan }\end{array}$ & $\sqrt{ }$ & \\
\hline
\end{tabular}




\begin{tabular}{|c|c|c|c|c|c|}
\hline \multirow[t]{2}{*}{ No } & \multirow[t]{2}{*}{ Modul } & \multirow[t]{2}{*}{ Data Masuk } & \multirow[t]{2}{*}{ Hasil Yang Diharapkan } & \multicolumn{2}{|c|}{$\begin{array}{c}\text { Hasil } \\
\text { Pengujian }\end{array}$} \\
\hline & & & & Sesuai & Tidak \\
\hline & & & tampilditabel & & \\
\hline & & $\begin{array}{l}\text { Klik Tombol } \\
\text { Koreksi }\end{array}$ & $\begin{array}{l}\text { Data yang terpilihakan aktif, } \\
\text { siap untuk dikoreksi }\end{array}$ & $\sqrt{ }$ & \\
\hline & & $\begin{array}{l}\text { Klik Tombol } \\
\text { Hapus }\end{array}$ & Data yang terpilih akandihapus. & $\sqrt{ }$ & \\
\hline & & $\begin{array}{l}\text { Klik Tombol } \\
\text { Tutup }\end{array}$ & Menu jenis kasus akan menutup & $\sqrt{ }$ & \\
\hline \multirow[t]{5}{*}{2.} & \multirow[t]{5}{*}{$\begin{array}{l}\text { Menu } \\
\text { Penyebab }\end{array}$} & $\begin{array}{l}\text { KlikTombol } \\
\text { Tambah }\end{array}$ & $\begin{array}{l}\text { Form akan kosong dan aktif siap } \\
\text { untuk entri data }\end{array}$ & $\sqrt{ }$ & \\
\hline & & $\begin{array}{l}\text { Klik Tombol } \\
\text { simpan }\end{array}$ & $\begin{array}{l}\text { Data penyebab kasus akan } \\
\text { bertambah dan akan } \\
\text { tampilditabel }\end{array}$ & $\sqrt{ }$ & \\
\hline & & $\begin{array}{l}\text { Klik Tombol } \\
\text { Koreksi }\end{array}$ & $\begin{array}{l}\text { Data yangterpilihakan aktif, siap } \\
\text { untuk dikoreksi }\end{array}$ & $\sqrt{ }$ & \\
\hline & & $\begin{array}{l}\text { Klik Tombol } \\
\text { Hapus }\end{array}$ & Data yang terpilih akandihapus. & $\sqrt{ }$ & \\
\hline & & $\begin{array}{l}\text { Klik Tombol } \\
\text { Tutup }\end{array}$ & $\begin{array}{l}\text { Menu penyebab kasus akan } \\
\text { menutup }\end{array}$ & $\sqrt{ }$ & \\
\hline \multirow[t]{5}{*}{3.} & \multirow[t]{5}{*}{ Menu Prosedur } & $\begin{array}{l}\text { KlikTombol } \\
\text { Tambah }\end{array}$ & $\begin{array}{l}\text { Form akan kosong dan aktif siap } \\
\text { untuk entri data }\end{array}$ & $\sqrt{ }$ & \\
\hline & & $\begin{array}{l}\text { Klik Tombol } \\
\text { simpan }\end{array}$ & $\begin{array}{l}\text { Data prosedur akan bertambah } \\
\text { dan akan tampilditabel }\end{array}$ & $\sqrt{ }$ & \\
\hline & & $\begin{array}{l}\text { Klik Tombol } \\
\text { Koreksi }\end{array}$ & $\begin{array}{l}\text { Data yangterpilihakan aktif, siap } \\
\text { untuk dikoreksi }\end{array}$ & $\sqrt{ }$ & \\
\hline & & $\begin{array}{l}\text { Klik Tombol } \\
\text { Hapus }\end{array}$ & Data yang terpilih akandihapus. & $\sqrt{ }$ & \\
\hline & & $\begin{array}{l}\text { Klik Tombol } \\
\text { Tutup }\end{array}$ & Menu prosedur akan menutup & $\sqrt{ }$ & \\
\hline \multirow[t]{5}{*}{4.} & \multirow[t]{5}{*}{ Menu Solusi } & $\begin{array}{l}\text { KlikTombol } \\
\text { Tambah }\end{array}$ & $\begin{array}{l}\text { Form akan kosong dan aktif siap } \\
\text { untuk entri data }\end{array}$ & $\sqrt{ }$ & \\
\hline & & $\begin{array}{l}\text { Klik Tombol } \\
\text { simpan }\end{array}$ & $\begin{array}{l}\text { Data solusi akan bertambah dan } \\
\text { akan tampilditabel }\end{array}$ & $\sqrt{ }$ & \\
\hline & & $\begin{array}{l}\text { Klik Tombol } \\
\text { Koreksi }\end{array}$ & $\begin{array}{l}\text { Data yangterpilihakan aktif, siap } \\
\text { untuk dikoreksi }\end{array}$ & $\sqrt{ }$ & \\
\hline & & $\begin{array}{l}\text { Klik Tombol } \\
\text { Hapus }\end{array}$ & Data yang terpilih akandihapus. & $\sqrt{ }$ & \\
\hline & & $\begin{array}{l}\text { Klik Tombol } \\
\text { Tutup }\end{array}$ & Menu solusi akan menutup & $\sqrt{ }$ & \\
\hline \multirow[t]{5}{*}{5.} & Menu Rule & $\begin{array}{l}\text { KlikTombol } \\
\text { Tambah }\end{array}$ & $\begin{array}{l}\text { Form akan kosong dan aktif siap } \\
\text { untuk entri data }\end{array}$ & $\sqrt{ }$ & \\
\hline & & $\begin{array}{l}\text { Klik Tombol } \\
\text { simpan }\end{array}$ & $\begin{array}{l}\text { Data rule akan bertambah dan } \\
\text { akan tampilditabel }\end{array}$ & $\sqrt{ }$ & \\
\hline & & $\begin{array}{l}\text { Klik Tombol } \\
\text { Koreksi }\end{array}$ & $\begin{array}{l}\text { Data yangterpilihakan aktif, siap } \\
\text { untuk dikoreksi }\end{array}$ & $\sqrt{ }$ & \\
\hline & & $\begin{array}{l}\text { Klik Tombol } \\
\text { Hapus }\end{array}$ & Data yang terpilih akandihapus. & $\sqrt{ }$ & \\
\hline & & $\begin{array}{l}\text { Klik Tombol } \\
\text { Tutup }\end{array}$ & Menu ruleakan menutup & $\sqrt{ }$ & \\
\hline
\end{tabular}


Aturan yang digunakan dalam sistem pakar ini :

a. Jenis kasus

Pada tabel 2 merupakan jenis kasus yang digunakan dalam menyelesaian sangketa tanah.

Tabel 2. Data Jenis Kasus

\begin{tabular}{|c|l|}
\hline Kode Jenis Kasus & \multicolumn{1}{|c|}{ Nama Jenis Kasus } \\
\hline JK01 & Sertifikat ganda \\
\hline JK02 & Tanah waris \\
\hline JK03 & Harta gono gini \\
\hline JK04 & Tanah adat \\
\hline
\end{tabular}

b. Penyebab Kasus

Tabel 3 merupakan penyebab terjadinya sangketa tanah.

Tabel 3. Data Penyebab

\begin{tabular}{|c|l|}
\hline $\begin{array}{c}\text { Kode Penyebab } \\
\text { Kasus }\end{array}$ & \multicolumn{1}{|c|}{ Penyebab Kasus } \\
\hline PK01 & Sengketa kepemilikan atas lahan orang lain \\
\hline PK02 & $\begin{array}{l}\text { Munculnya dua sertifikat tanah dengan data yang berbeda } \\
\text { di atas tanah yang sama }\end{array}$ \\
\hline PK03 & $\begin{array}{l}\text { Ketidak telitian petugas pertanahan dalam melakukan } \\
\text { pengecekan dan penelitian terhadap tanah yang } \\
\text { dimohonkan }\end{array}$ \\
\hline PK04 & Belum dewasa saat mendapat tanah waris \\
\hline PK05 & Tidak adanya surat waris terhadap tanah yang diwarisi \\
\hline PK06 & Tidak adanya peralihan hak atas tanah \\
\hline PK07 & Perebutan harta waris \\
\hline PK08 & Kedua belah pihak menginginkan harta bersama tersebut \\
\hline PK09 & $\begin{array}{l}\text { Salah satu pihak berniat tidak baik ingin menguasai harta } \\
\text { bersama secara utuh }\end{array}$ \\
\hline PK10 & Adanya klaim dari masing-masing pihak yang bersengketa \\
\hline PK11 & $\begin{array}{l}\text { Adanya pergeseran batas patok pada tanah yang di } \\
\text { sengketakan }\end{array}$ \\
\hline PK12 & \begin{tabular}{l} 
Pemakaian secara pribadi di atas tanah adat \\
\hline
\end{tabular} \\
\hline
\end{tabular}

c. Data solusi

Tabel 4 terdapat empat solusi penanganan kasus sangketa.

Tabel 4. Data Solusi Penanganan Kasus

\begin{tabular}{|c|l|}
\hline $\begin{array}{c}\text { Kode } \\
\text { Solusi }\end{array}$ & \multicolumn{1}{|c|}{ Solusi } \\
\hline S01 & $\begin{array}{l}\text { a. Pengecekan kembali keabsahan masing-masing sertifikat di badan } \\
\text { pertanhan } \\
\text { b. Melakukan pengukuran ulang terhadap tanah yang memiliki } \\
\text { sertifikat ganda } \\
\text { c. Musyawarah antara klien dan calon tergugat dengan melibatkan } \\
\text { perangkat desa dan masyarakat setempat sebagai saksi atas } \\
\text { terbitnya dua sertifikat di atas lahan yang sama }\end{array}$ \\
\hline
\end{tabular}




\begin{tabular}{|c|l|}
\hline & d. Apabila musyawarah mendapat titik temu, maka penyelesaiaan \\
& kasus dapat di tempuh dengan cara damai. Dengan ketentuan \\
& salah satu pemegang sertifikat menggugurkan hak atas sertifikat \\
sertifikat yang sama pada lahan yang di sengketakan atau dengan & cara ganti rugi kepada pemilik sertifikat yang sah atas lahan yang di \\
sengketakan & e. Apabila musyawarah tidak mendapatkan titik temu, maka kasus \\
berlanjut pada proses hukum sampai di dapatkan kepastian hukum \\
yang tetap
\end{tabular}

d. Data Rule Penanganan Kasus Sengketa Tanah

Tabel 5 merupakan rule yang digunakan pada sistem pakar.

Tabel 5. Data Rule Penyelesaian Kasus Sengketa Tanah

\begin{tabular}{|c|l|l|}
\hline $\begin{array}{c}\text { Kode } \\
\text { Rule }\end{array}$ & \multicolumn{1}{|c|}{ Keterangan } & Solusi \\
\hline R01 & IF JK01 AND PK01 AND PK02 AND PK03 THEN PPK01 & S01 \\
\hline R02 & $\begin{array}{l}\text { IF JK02 AND PK04 AND PK05 AND PK06 AND PK07 THEN } \\
\text { PPK01 }\end{array}$ & S02 \\
\hline R03 & IF JK03 AND PK08 AND PK09 THEN PPK01 & S03 \\
\hline R04 & IF JK04 AND PK10 AND PK11 AND PK12 THEN PPK01 & S04 \\
\hline
\end{tabular}




\section{Pembahasan}

Berdasarkan implementasi sistem pakar ini dengan pengujian mengangkat kasus tanah waris, dengan penelusuran penyebab kasus diawali dari belum dewasa saat mendapat tanah waris, tidak adanya surat waris terhadap tanah yang diwarisi, tidak adanya peralihan hak atas tanah dan perebutan harta waris. Aplikasi sistem pakar menghasilkan dengan menampilkan prosedur penanganan klien perlu konsultasi dengan lawyer dan meminta pendapingam hukum dengan lawyer. Serta meberikan solusi yang kepada klien adalah adanya perwalian dari si penerima waris apabila belum dewasa/cukup umur sampai si penerima waris tersebut di anggap dewasa, musyawarah keluarga dalam hal menentukan siapa yang berhak menerima tanah waris bila si pewaris tidak memberikan surat waris terhadap tanah yang di wariskannya, melakukan peralihan atas tanah yang di wariskan kepada si penerima waris agar hak atas tanah tersebut menjadi milik si penerima waris seutunya dan melakukan proses hukum apabila terjadi perebutan atas tanah waris yang dapat merugikan si penerima waris yang sah atas haknya

\section{Tampilan Menu Awal}

Ketika pertama kali aplikasi dijalankan maka menu awal terdapat 3 tombol yang tersedia, yaitu: tombol Menu Admin, Menu Klien, dan Menu Keluar seperti pada gambar 2.

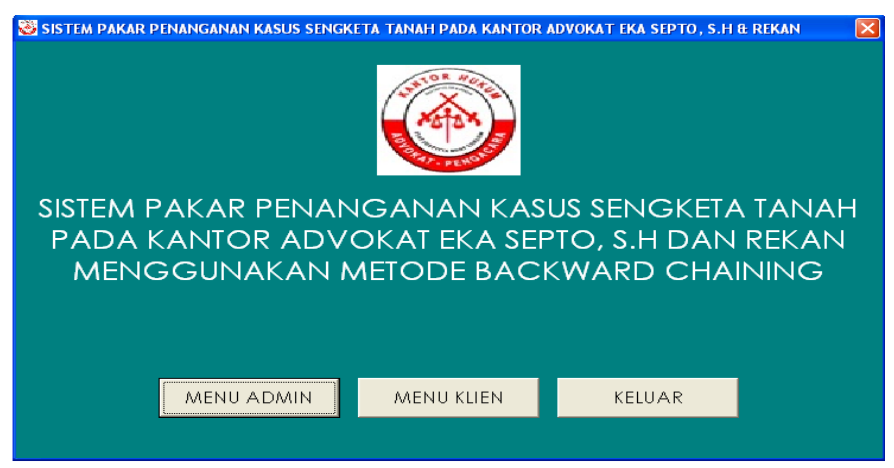

Gambar 2. Tampilan Menu Awal Sistem Pakar

Setelah berhasil melakukan login maka pada gambar 3 merupakan sub menu admin, yaitu: Jenis Kasus, Penyebab Kasus, Prosedur Penanganan, Solusi, dan Rule, akan aktif dan dapat digunakan untuk memasukkan data yang dibutuhkan oleh sistem. 


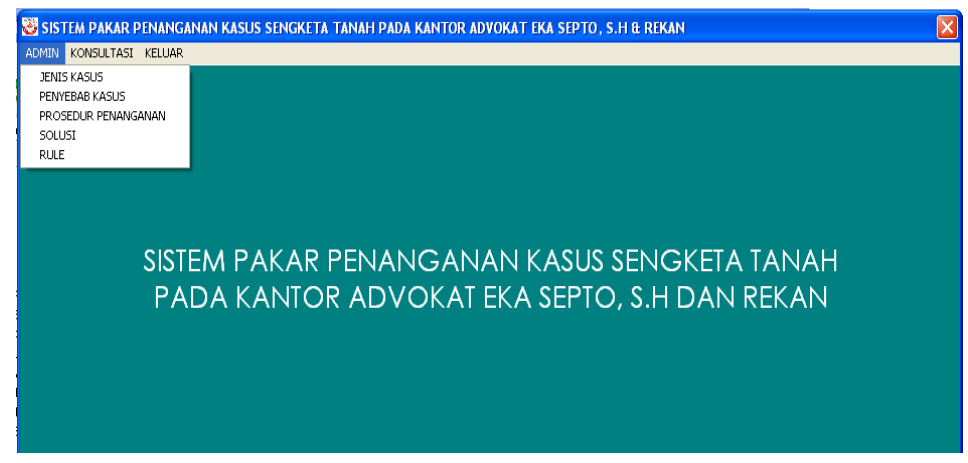

Gambar 3. Tampilan Menu Utama

a. Menu Rule

Menu ini digunakan untuk menambah, memperbaiki dan menghapus data rule dalam penyelesaian kasus sangketa tanah. Tampilannya dapat dilihat pada gambar 4.

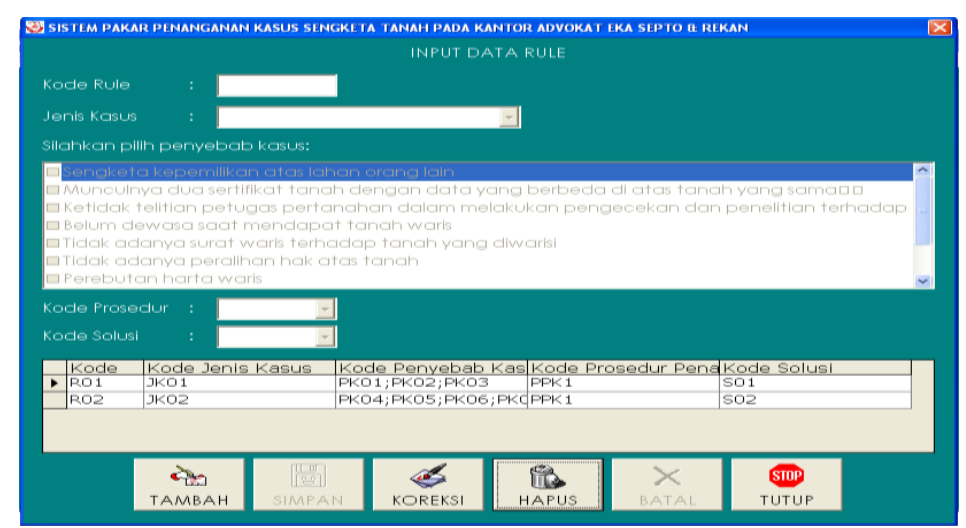

Gambar 4. Tampilan Input Data Rule

b. Menu Konsultasi

Menu ini digunakan untuk melakukan konsultasi yang berkaitan dengan penanganan kasus sengketa tanah. Tampilan dalam melakukan konsultasi dengan memilih jenis kasus seperti gambar 5 .

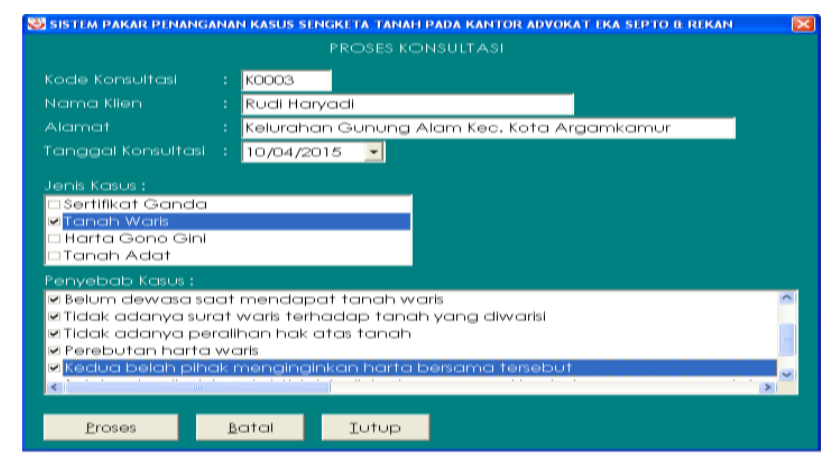

Gambar 5. Tampilan Proses Konsultasi 
Dan hasil dari konsultasi tersebut maka akan memberikan informasi solusi terhadap konsultasi yang dilakukan seperti gambar 6 .

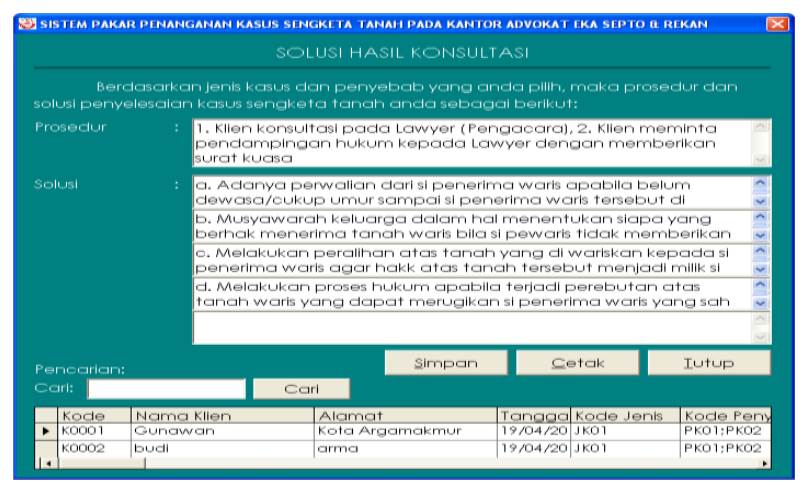

Gambar 6. Jendela Hasil Jika Rule Sesuai

Hasil konsultasi dari sistem pakar ini dapat dilihat pada gambar 7.

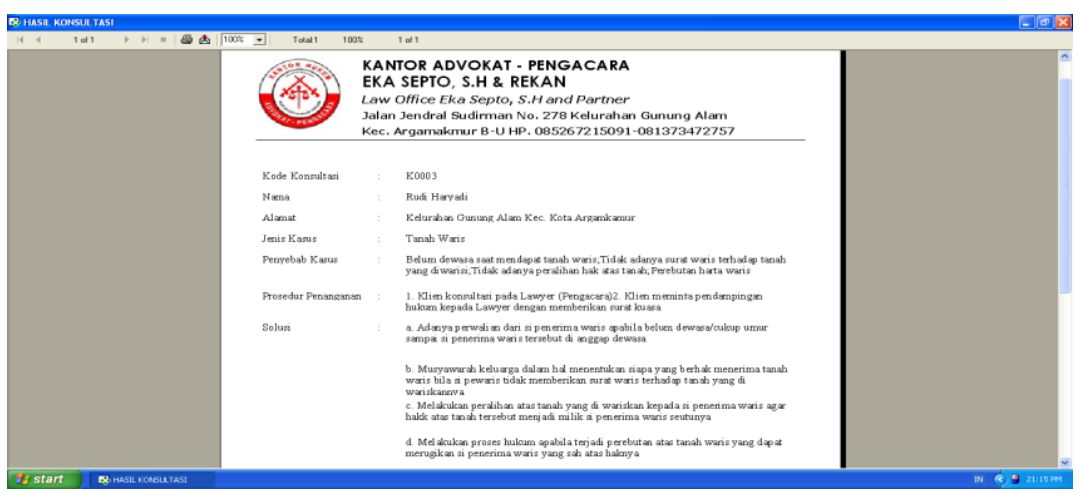

Gambar 7. Hasil Konsultasi

\section{Kesimpulan}

Berdasarkan hasil penelitian dan pembahasan dapat disimpulkan sebagai berikut:

1. Aplikasi sistem pakar yang menerapkan rule-rule pada backward chaining menghasilkan inferensi dan reasoning serta penjelasannya dapat menyelesaikan permasalahan sangketa tanah. Kasus sangketa tanah dengan pendekatan menginputkan penyebab kasus sangketa tanah kemudian program akan melakukan penghitungan nilai probabilitas. Nilai probabilitas tertinggi-lah yang nantinya akan diambil. Rule yang memiliki konsekuen untuk menampilkan hasil solusi dengan cepat dan tepat.

2. Sistem pakar ini dibuat sesuai dengan kebutuhan dan dirancang sedemikian rupa sehingga bisa mencari solusi dan dapat mewakili dari pakar tersebut, dan sistem pakar ini berdasarkan Rule dari Pengalaman, Keahlian, Pengetahuan, yang dapat disimpan dalam satu database sehingga dapat digunakan berulang-ulang dimana 
tempat secara konsisten, kecepatan dalam memberi petunjuk/ solusi yang lebih cepat.

\section{Daftar Pustaka}

Asti Herliana, Visqia Ade Setiawan, Rizki Tri Prasetyo, 2018, Penerapan Inferensi Backward Chaining Pada Sistem Pakar Diagnosa Awal Penyakit Tulang, Jurnal Informatika Vol.5 No.1 April 2018, 50-60

Dahria, Muhammad. 2012. Implementasi Backward Chaining untuk Mengetahui Kerusakan Monitor Komputer. Medan : Saintihom

Desiani, A. dan Arhami, M. 2006, Konsep Kecerdasan Buatan, Bandung, Sinar Baru Algessindo

Evi Dewi Sri Mulyani, Teuku Mufizar, Indah Novianti, 2015, Perancangan Aplikasi Sistem Pakar Pembagian Harta Waris Menurut Islam Menggunakan Metode Backward Chaining, Seminar Nasional Teknologi Informasi dan Multimedia 2015 ISSN : 2302-3805.

Kusrini. 2006. Sistem Pakar Teori dan Aplikasi, Bandung : Sinar Baru Algessindo

Suryadi, HS. 2005. Pengantar Sistem Pakar, Bandung : Sinar Baru Algessindo 